\title{
TOWARDS ENTREPRENEURSHIP: REFLECTIONS BETWEEN THEORY AND PRACTICE
}

\author{
Tereza BENEŠOVÁ \\ Innovation Support Centre, VŠB - Technical University of Ostrava
}

\begin{abstract}
:
The paper deals with the pragmatic need of linking theory and practice in the learning process, focusing on vocational education in economics and entrepreneurship education. In connection with selected alternative economic theories is shown the necessity of praxeological educational background and practical work experience in teaching process in entrepreneurship education. Results are based on the research, which was done in the framework of prepared dissertation thesis on the theme of entrepreneurship education from the perspectives of theory and the perspective of vocational school teachers of economics subjects. The results focus on the concept of entrepreneurship education preferred by teachers of the economical subjects at the secondary schools specialised in economics. The main aim of the research was to check, to what degree are the theoretical bases of the education of the entrepreneurship fulfilled in the reality of a secondary school specialised in economics. The results show that in the case of preferred aims of the respondents of our examination we could talk about the combination of creation of knowledge and preparation for the profession. It is confirmed that the teachers rely significantly on a prescribed list of educational topics, but at the same time the results clearly show that the respondents think about their subject and formative aspect of their classes through using of cross-sectional topic.
\end{abstract}

\section{KEY WORDS}

entrepreneurship education, late modernity, reflexivity, facilitation

\section{JEL CLASSIFICATION}

A22

\section{DECISION MAKING UNDER UNCERTAINTY AND RISK}

The postulate of uncertainty as an integral part of our (not only) economic life, as was formulated by John Maynard Keynes more than seventy years ago (Keynes, 1936), and rejection of prognostic pride of economics of the mainstream is now, in the wake of economic crisis, viewed as a necessary condition for understanding human behaviour. 
Uncertainty in the ontic sense of a Post-Keynesian explanation ${ }^{1}$ is viewed as an inherent feature of the world, which does not prescribe, what will happen, but what can happen (Shackle, 1969). This uncertainty comes from human action, which is irreversible and changes circumstances and conditions so that they cannot be repeated in the absolute meaning of the word. The human ability to make decisions and to influence not only surrounding conditions, but also the human, however, does not correspond to the image of mechanical calculation, as is favourably used in economics, as a mathematically-allocated science ${ }^{2}$.

A decision is in this sense a creative act the result of which is not defined by natural necessity, but is in its own way a self-destructive experiment (Shackle, 1969; Svoboda, 2002). This means that every piece of knowledge we obtain causes qualitative change inside of us. This approach corresponds to the basis of the conceptions of procedural rationality or theory of limited rationality and critics of neoclassical economics ${ }^{3}$, create many implications (not only) for professional economics education.

The flow of Post-Keynesianism does not forget the fact that human knowledge is fallible in that it is a social product, reminding us of how (not only economic) subjects view uncertainty; it is given not only by personal values, cultural and social patterns, but also by (not only economics) theories influencing them (Svoboda, 2002). That involves questions of theoretical concepts and their influence on thinking and acting.

We will limit ourselves, in this article, on the consideration of the character of knowledge, which is based on a realisation of the changing of the outer and inner worlds, and the way it accepted.

\section{1 Second age of modernity}

The acceptance of uncertainty comes together with a theses of the second age of modernity (Beck, 2004, 2006; Keller, 2007), or late modernity (Giddens, 2003; Chisholm, 2008; Navrátil, 2009). The impeachment of a scientific way of knowing and the validity of theories which we wrote about in relation with Post-Keynesianism comes through the social sciences. Searching for one objective truth is subsidized by a sensitive and critical evaluation of rival explanations (Navrátil, 2009). The important consequences of late modernity are concepts of personal and theoretical reflexivity (Beck, 2004, Giddens, 2003; Lynch, 2000; Navrátil, 2009). Reflexivity in the meaning of the deconstruction of objective knowledge, revaluating the way of thinking about things, especially in connection to critical theoretical reflection and the reflexive (my)self (Giddens, 1991) is an important impulse for our debate.

The present society of knowledge or society of understanding, that is society with a decisive role of human capital and the externalisation of creative functions, is characterised by the growing pressure of demands on high and constantly innovative knowledge, the need for creating unique technologies, products and systems, reflectively made knowledge and other features from the

\footnotetext{
${ }^{1}$ Post Keynesian economics is one of approaches, which representatives complement and reinterpret Keynesian theory. It attempts to supplement Keynesian theory of effective demand, not only with imperfectly working markets, but also with alternative theories of dividing, value and money, which could allow to form from Keynesian theory adequate alternative to neoclassical economics.

${ }^{2}$ For example, Tomáš Sedláček (2009) points out the problems of present economics science, which is excessive shift to mathematisation of economics theory.

${ }^{3}$ These are post-classical approaches, which affect argumentation routine of paradigm homo oeconomicus (Hlaváček, 1999).
} 
collateral phenomenon of present society, for which there is in many studies and analyses the term era of symbolic analytics ${ }^{4}$ coined by American economist and sociologist Robert Reich (1995). The authors from the Institute for Research and Development of Education Institute of the Faculty of Education of Charles University (Černý \& Greger, 2007) warn about growing demand for knowledge workers and about a gradual change of professional structure and job market that is in need of higher qualification and with this related higher participation on formal and informal education. The reflections of this demand are then gradual changes in social stratification ${ }^{5}$ that is also the danger of disconnection of elite of society of knowledge from the rest of the population.

Generally speaking we can say that the economic-social changes in recent years have to be reflected in the processes of drafting of curriculum ${ }^{6}$, if we take into the account that the curriculum is not understood as a changeless construct, but as a dynamic process, which evolves and changes and is influenced by different types of situations (Beran, Mareš \& Ježek, 2007).

On the other hand, the revision of demands put on the education for the society of knowledge cannot lead only to escalation of new and new topics, or to a non-conceptual matching of content of education to the most actual economic-social situation.

All efforts for a progressive curriculum, so called curriculum of future (Černý \& Greger, 2007), cannot be realized without a balanced approach between the will to react on the actual needs of the society, the job market and awareness of anthropological dimension of education, which deals especially with cultivation of a personality of a young person, enriching his or her inner experiences, be it from the understanding, or from the experiencing of the subject matter, or interpersonal relations, which the school and its education offer. Here belong the creation of a basic value orientation, the knowledge of one's place in the system, the knowledge of relation of one to another. How a person decides, which of these influences lead him or her through life, what plans does one have and where does one head (Skalková, 2007).

With a reference to the period of the late modernity and its changeability, we cannot omit tendencies to wipe borders between education and work. The approach based on the competencies is often connected to the job market, employability and to the ability of a person to actively and without problems deal with complex, quickly changing tasks ${ }^{7}$ (Janík 2005; Janík et al., 2010; Janík \& Slavík, 2011). Factual knowledge and routine skills are becoming less and less sufficient and adequate skill set of a person (Chisholm, 2008). New topics are put into the curriculum of the present school and there are new demands. Solutions of problems, the analytical critical thinking, the reflexive way of creation of knowledge, the ability of self-directing and other required skills for

\footnotetext{
${ }^{4}$ The symbolic analyst (sometimes not exactly identified with known expression from Peter Drucker ,knowledge worker") is in a concept of Reich and following authors ideal representative of society of knowledge. The symbolic analyst is highly professionalised, competent, and globally mobile. Among key skills of symbolic analysts belong ability of abstraction (work with models, formulas, and analogies), system thinking (connection of notes from different areas), and ability to experiment and learn on the base of experience (reflectively formed knowledge), creativity and teamwork.

${ }^{5}$ We speak about a social analogical stratification with division of the job market into three segments, where upper $20 \%$ is formed by highly professionalised people, on the opposite lower $20 \%$ are unemployed people, not able to revise and complement their knowledge. Broadest segment covers $60 \%$ of able to work persons, who are, however, very vulnerable to quick changes of qualification (for example Černý, Greger, 2007)

${ }^{6}$ The curriculum is understood here in a broader meaning of this term. As an content of all experience, which students get at school and from activities connected to school, its planning and evaluation (Průcha, Walterová, Mareš, 2008).

${ }^{7}$ The goal of the article is not to be concerned deeply by the critical discussion about the term - key competencies. The use of this term has its source mainly in the concept of competency, how it is suggested by Janík, Maňák, Knecht ( Janík and collective 2010)
} 
new jobs ${ }^{8}$ return attention to the formative task of education and the interdisciplinarity not only in the sense of the connection of knowledge from different subjects, but also in the meaning of the connection of education in an area of taught subjects with the learning in other contexts (for example at workplace), leading to a desired innovative reconfiguration of knowledge.

\subsection{Professional knowledge: knowledge on the edge of learning and work}

If we shift the attention to the area of professional education ${ }^{9}$, in relation with succinctly formulated professional profiles of graduates ${ }^{10}$, competency approach is offered (in the meaning of getting the qualification for a certain activity) as completely natural. Is it really so and is it enough? Chisholm (2008) in the relation with displays of late modernity warns that present society works in a larger scale without any borders and limitations. This means that personal, social and professional paths are more and more differentiated and individualized. He shows as an example the hierarchy of educational motives, needs and preferences:

Individuals are not divided into separated drawers with signs "general education" and "specialised education". In the real life these categories overlay one another and this pragmatic interconnection is evident in everyday use of knowledge and competencies (Chisholm in Novotný Eds., 2008, page. 63, translated from Czech by author 2014)

Obtaining of specialisation in the meaning of getting a qualification for job, supported by the inductive construction of knowledge (Janík, 2005), at best in an active experience of practical action, is viewed as optimal from the point of view of demands of dynamic present.

Chrisholm (2008) further expresses persuasion that individuals who actively learn themselves, reflexively, decide about what can be understood as knowledge, which knowledge belongs to one another and how it can be used. If the learning subject is so self-interpretative and builds primarily on the reflection of his or her own experience, what relation to the practical knowledge, is the knowledge gained by science and research ${ }^{11}$ ?

The basis for the consideration about the character of this relation is an example of training for enterprise in specialised education of economics.

\section{QUESTIONS ABOUT THE EDUCATION OF ENTREPRENEURSHIP AND ENTERPRISE}

In accordance with a competency approach, we come across with prescriptive demand in specialised economics education, but we also realistically see the need of development of competency for initiative and enterprise skills.

A common denominator in terms of enterprise competency, development of spirit of enterprise, a competency for enterprise, a sense for initiative and enterprise (which cannot be seen as pure

\footnotetext{
${ }^{8}$ New Skills for New Jobs is a common social political initiative of European commission from states of EU. See: European Commission (2009): New Skills for New Jobs: Anticipating and matching labour market and skills. Luxembourg: Office for Official Publications of the European Communities.

${ }^{9}$ Specialised education (vocational education) covers a vocational preparation work of non-university type. (Průcha, Mareš \& Walterová, 2008)

${ }^{10}$ General educational programmes (NUOV, 2007).

${ }^{11}$ More about the category of knowledge see In Janík, 2005.
} 
synonym $^{12}$ ), is the acceleration of the human potential, be it in social-economic development or in a more intimate level of personal development, including personalisation of values and approaches, such as a sense for initiative, independence, readiness for innovations in personal and social life and at work.

A politically-social context of the concept of the key competencies and requirements set on the education in area of competences in European Union at the same time put enterprise into the position of main categories of school education.

The hallmark of actuality is given by the possible trends of evolution of education and work towards actuality of requirement of cultivation of enterprise through the education and the training, in a larger context of social changes, as they are presented by all kinds of prognoses and scripts for the future with the forecast of higher work fluctuation, mobility, a need of self-employment, creativity, critical thinking etc.

The question how we should approach the problematic of support of the enterprise in the training and educational process comes after the question why we should concentrate on the enterprise. The teachers are the main agents in the reality of educational process - they change approach towards new topics in education and provide needed competencies.

According to Gibb (2007), acceptance of an appropriate and modern concept of development of enterprise and education of entrepreneurship needs among others:

- a larger integration of knowledge (in scheme of educational institution, among different branches, among art sections and science, among tacit and explicit knowledge);

- a larger interdisciplinarity of education;

- $\quad$ more opportunities for experience learning;

- $\quad$ a larger area for validation of explicit knowledge in practice (more time for reflection and learning of activities themselves);

- $\quad$ larger balance in emphasis on what is taught and how it is taught;

- $\quad$ an innovation in evaluation of programmes and accreditations;

- $\quad$ changes in some basics of philosophy of education.

\subsection{Content of education of entrepreneurship}

Johannisson (1991, according to Fayolle, Gailly \& Lassas-Clerc, 2006) distinguishes five levels of content of development of entrepreneurial behaviour: know-why (approaches, values, motivations), know-how (skills), know-who (short and long term social skills), know-when (intuition) and knowwhat (knowledge). Johannisson (ibid) warns that traditional education of enterprise contains too much mostly declarative knowledge about partial processes during setting up of a business and running of a company, and that most programmes of economic education, which concentrate on enterprise are unilaterally aimed (Gibb 2007, Kirby, 2002). But content of such education of enterprise does not correspond to activities, which entrepreneurs do after starting of their business in reality (Gibb, 2007; Malach, 2008) and it does not reflect alternative theories of economics, which are close to the realistic enterprise process in concept of procedural rationality and which in

\footnotetext{
12 The English terminology, which works with the term of entrepreneurship education (common in European curricular documents), usually does not differentiate between the terms training and education, it is not only about teaching entrepreneurship, but also about entrepreneurial education (meant as education for a job - education of the future entrepreneur), and also about the training for enterprise (cultivation and development of certain specific quality entrepreneurship).
} 
opposite of theory of the mainstream does not abstract from imperfections in process of economic decision making and takes into account enframing of the process.

It is possible to state that the education of entrepreneurship is not often accepted in broader concept as a development of behaviour of enterprise and does not take into the account the fact that it can come to an enterprise acting in all kinds of environments that the enterprising behaviour is framed by a context of surrounding world, personal qualities and motivation.

A theoretical answer for this imperfection in training for enterprising can be concept of effectuation $^{13}$, which in the present represents an influential approach to research, how entrepreneurs act, think and what do they do. Main points of this theory can be summed up like this (Sarasvathy, 2008):

Experienced entrepreneurs:

- $\quad$ base on the knowledge who they are, what they can do and who do they know;

- $\quad$ immediately act and enter interactions with other people;

- $\quad$ concentrate on what they can do, without large worries about what they should do;

- $\quad$ share some of the interactions and acting, give and bring commitments, which they can contribute to a given purpose;

- $\quad$ know that each commitment leads to new instruments and new goals;

- $\quad$ gradually gather sources that lead to clarifying of aims, decreasing of possibilities of change and creation of network of interested people;

- make goals and network gradually come closer together into new market and new companies.

This approach convenes with the theses of procedural rationality: an individual is constantly forced to confront his conceptions; equipment of perceptive and behavioural habits and to evaluate his possibilities with a changing reality and at the same time is equipped with the ability of adaptation and learning. Personal flexibility, awareness of insecurity and instability define to a certain rate the quality of one's life. At the same time with regards to the environment of a fundamental insecurity, a person is never able to objectively maximize benefit, as it is presumed by neoclassical economics. In the end, defining are not our goals, but our actions.

An example of a procedural rationality in an economical thinking, not to say a concept of effectuation represented by research activities of Society for Effectual Action, introduces suitable theoretical bases for an effective training for enterprise. Normatively oriented images, classic managing economics (especially in a relation to process of enterprise) cannot reflect reality; it abstracts from a changeable base of a relation of an individual self and the environment. The concept of dynamically influencing forces, as it is brought up for example by Saravathy (2005, 2008), takes advantage from the reflection of experience, it has praxeological character.

The main agents of changes during education in approach to new topics in education and intercession of needed competences are the teachers.

An emphasis on ability of synthesis of notes, on discovering, implementation of students into practical activities, orientation on creation of new ideas, opening of original views, which is essential for support of enterprise thinking and enterprise abilities goes hand in hand with an basic functional choice of the content of education goes hand in hand the

\footnotetext{
${ }^{13}$ Author of the concept of effectuation is professor Saras D.Sarasvathy, who under the influence of Herbert Simon and his theory of procedural rationality (bounded rationality) and researches among expert entrepreneurs, supports concept of enterprise as a dynamic and highly interactive process.

Research platform for development of concept of effectuation is Society for Effectual Action.

http://www.effectuation.org/
} 
A defining and necessary factor of enterprise education and training is also a stimulating environment, sharing of experiences and suitable didactic tools, among which can be labelled as most effective those, which support learning "through life and experience", this means through practice (coaching, mentoring and facilitation), stimulation, experiments, creative problem solving, discussions, role playing and last but not least reflection of models and outer world.

Králová (2007) defines the areas of desirable change in secondary education of specialised economics as follows:

- $\quad$ a setting of general knowledge basics;

- $\quad$ an adjustment of specialised content to evolution of new technologies;

- $\quad$ organisation of work.

Based on these demands, the attention of the teachers of specialised economics subjects concentrates especially on the area of organisation of work in education (VŠE, 2007). Support of creative force of an individual, one's self-reflection and an interaction with environment, emerges especially during considerations about suitable didactical techniques, teaching methods and organisational forms of teaching. There is a risk of purposelessness in the creation of these innovative educational processes without the link to the theory and the consequences with the content of education.

If we look under cover of activities and processes in present most known and spread projects supporting enterprise in education (student companies, fictional companies, Simgames, business games and so on $)^{14}$ we get the common denominator: learning through simulation in the safe scheme of a fictional world how to react to challenges of the real world. In newly tried roles (work relegation, work duties and responsibility) students keep their own personal characteristics and enter the process of decision making in model situations, problem solving and at the same time they realise their personal and social awareness.

We are getting beyond the borders of "simple" interactive game, which models professional or life situations, which is understood as an opportunity to try one's abilities in an area, where he or she does not risk anything (Petty, 2008). In context of the cognitive behavioural theory it is especially about the development of ability to know, and how to organize what we know according to certain aspects, to distinguish mutual connections, to anticipate, detect mistakes in own cognitive process and to know how to dispose them by the use of the reflexive approach; that means a way to a new style of thinking and behaving.

The core of efficiency of simulation games or role playing in the meaning of a certain complex learning activity, where students in many roles get to know a simplified model of reality (Pasch,1998) is not based "only" on getting new skills, but also on the facilitation of the inner process of change. The modelling and rehearsing of roles and skills goes together with the realisation of functional and not functional behaviour, approaches and further self-reflection.

The teacher in such education does not fill only the role of a specialist (theoretical knowledge of topic, but also field didactics), but he also fills the role of a reflective practician (reflexion of own experience, naming of process and a concept knowledge) and also a role of a sensitive facilitator (accessing and providing of desired values and attitudes).

\section{TEACHER OF VOCATIONAL ECONOMICAL SUBJECTS IN CHANGES OF ROLES}

\footnotetext{
${ }^{14}$ Detailed information at: www.simgame.org, www.nuov.cz/index.php?page=cefif, www.jacr.cz, www.businessgames.cz
} 
„In the present situation majority of teachers has not gone through a specialised training for teaching of entrepreneurship. They may not realise the correct approach to the education. The teachers should better understand the entrepreneurship education and its aims, methods and content. It is necessary to provide more specialised preparation, seminars and workshops and spread understanding of different ways and methods for support of entrepreneurial thinking." (European Comission, 2009, page 24, translated from Czech)

The knowledge of field, the skills and the experiences of teachers are, of course, the pillar on which it is possible to build a meaningful construct of an entrepreneurial education. It is necessary to emphasize the premise that "the entrepreneurial education should not be changed with general business, or commercial studies, because its main aim is to support creativity, innovation and selfemployed people for consideration about needed components of teaching and training for enterprise and entrepreneurship" (European Comission, 2009, translated from Czech).

This premise corresponds with the statement of American philosopher and founder of modern management, Peter Drucker that from the point of view of the job market, the preparatory education on universities has to prepare students much more for all life employment than for a particular job (Drucker, 2004).

Besides knowledge "about entrepreneurship" it is necessary to emphasize not only the connection of theoretical notes with practical skills, but also their practical "validation", testing in reality, or experimenting.

Specific, supporting, didactical tools created for the support of the education of entrepreneurship, or the training for the enterprise, cannot fill their purpose by themselves and lead to the given goals without a good guide and a facilitator of process of learning. The teacher is in the position of organiser, motivational agent, and supplier of feedback, be it in the demanding process of leading of fictional company, or "only" in analysis of case study. This means that teacher suggests and leads more, than just gives orders. He learns together with the students, he works as a diagnostician, helps to solve discords and hardships, which can arise, inspires and guarantees safe environment.

The success of a supportive process depends not only on the whole set of communicational skills, such as active listening, ability to negotiate and work in teams etc., but it also depends on a sensitive bonding of oneself with the group, in an awareness of ones integrity, an ability to become a mirror of collective work and an ability share collective experience of learning.

A very fragile balance should be kept by the teacher also in the question of goal, which should be reached by the group work. The facilitator should know and monitor his goal, and at the same time respect possible borders and limits, or on the other hand talents of members of his group. This means not only the teacher's own self-reflection, but also knowledge of abilities, imaginations and aspirations of those who he leads - only this is how it is possible to choose a forceful way of leading and to harmonize the creativity of all involved.

It is not possible to presume that each teacher (present and future) is equipped with the ideal amount of intuition, emotional intelligence and belief which makes the process of facilitation natural for him. Usually a part of this process is a certain amount of inner or outer resistance. Anti-resistant strategies then unwind in intentions of successful or practical intelligence theories and their characteristics: an ability to learn from experience, openness to change, interpersonal skills and more and more required ability of self-reflection and reflection of practical (Lazarová, 2005).

The term reflexivity in pedagogical practice emerges from its broad semantic field especially in the meaning of looking back and evaluation of acting. Looking back should be implemented into the 
future actions. So the required reflection will not be only a reproduction, but will be somehow an epoche, over stepping everyday reality is needed, it is necessary to open to the reflection connected to the ability of realising of contexts and the relativity of reflected knowledge, its dependence on perspective of the person involved, which is created by a volume of knowledge and personal components, components of values, or approach.

In balance with the theory of constructivism it can be noted that there is not reality "by itself" that it does not make sense to speak about it, without being aware of an constitutive process, which is based on the mutual acting between knowing and known.

The teacher in the position of the reflective practitioner (Janík \& Slavík, 2011) and the facilitator in the process of the training for the enterprise should realise himself that even public discursus about the entrepreneurship (or the enterprise) is not homogeneous and there are many statements said from different positions, with different motives. During the analysis of the discursus it is necessary to respect its diversification and to respect contexts in which are said partial opinions. The teacher can be the creator of own coherent argumentation, which is an integrating element of process of teaching (learning) only based on such sensitive, reflective acting.

The theory helped us to map the concepts of entrepreneurship and the theoretical approaches towards the development of the entrepreneurship and helped us to identify three topical areas, which form a complementary whole of the education of the entrepreneurship, and which can be related to the theory of an accented holistic view of the entrepreneurship based on three pillars: the personality of the entrepreneur - the social context of the entrepreneurship - the entrepreneurship as the process of the growth. We monitored three main topical areas (personal, social and work), in the scheme of the education of the entrepreneurship, which is related to a theoretical basis.

The teacher and the teacher's thinking about the pedagogical reality and its intentionality, directivity are the key conditions for an efficient education of the entrepreneurship. The effective education of the entrepreneurship consists also, as we pointed out, of important determinants, such as the context of the culture of the school, the community and outer environment, where the theoretical notes brought a request for a guidance of the education of the entrepreneurship through enterprise, be it real or just practice and the request for a tight connection to the real world of the enterprise.

The main aim of our research was to check, to what degree are the theoretical bases of the education of the entrepreneurship fulfilled in the reality of a secondary school specialised in economics. The chosen basic perspective for the checking was the point of view of the teachers of economical subjects and their concept of the aim of the education. The main research question focused on the concept of the aim of the education of the entrepreneurship by the teachers of the economical subjects at the secondary school specialised in economics.

Partial questions were connected to the main research question. These questions were related to other chosen determinants of the education of the entrepreneurship which are identified in the theoretical part of the thesis. In the relation to the fact that the respondents inclined more to the aim category of knowledge, we can see them generally as a type of a person who concentrates on the education and training. These persons concentrate on the educational questions more in general, than on the level of the individual student and this person relies on the knowledge of the field.

334 respondents of online questionnaire in our research - the teachers as the whole, significantly inclined to the choice of the educational aims in the area of the knowledge and in the topic area of work and employment. The results show clearly that in the case of the preferred aims of the respondents of our examination, we could talk about the combination of the creation of the knowledge and the preparation for the profession. It is confirmed that the teachers rely significantly on a prescribed list of educational topics in the school curriculum, but at the same time the results 
clearly show that the respondents majorly apply a cross-sectional topics in their classes. This means that they also think about their above subject and formative aspect of their classes, what corresponds with the holistic trends of entrepreneurship education.

\section{CONCLUSION}

The late modernism is with its perception of a person as a social being with limited rationality, moving in a world of uncertainty, finds its reflection in social sciences including economics. The originality of individual life paths, project of reflective me and an essential relation of the social life creates a scheme for consideration, what declarative, procedural knowledge, and what attitudes and experiences should be goals in the education of specialised economical subjects.

An agreement is in a harmony with a competency model in preparation for a certain personal alertness, preparation for performance, a decreasing of space between learning and practical reality. In the connection to the training for the enterprise there are possible some specific didactic tools based especially on the simulation of real activities in the enterprise. The real learning through practice requires, besides providing opportunity for acting, also providing of opportunities for selfreflection and for reflection of a theory.

If practice should lead to restructuring of the theoretical knowledge and its relation to own skills, abilities and approaches, as to the environment and other outer subjects, in a way it is demanded by the modern conceptions of the education of the enterprise and the training for the enterprise, it is necessary to count with a support of the reflexive process behind theory and practice.

This support can be provided in the educational process by the teacher with facilitation equipment, who admits that fundamental insecurity influences decisive processes not only in the process of the enterprise, who admits the plurality of individual and social bases and the need to reflectively consider how to connect theoretical contents with practical action.

\section{REFERENCES}

Beran, J. \& Mareš, J \&. Ježek, S. (2007) Rezervované postoje učitelů k dalšímu vzdělávání jako jeden z rizikových faktorů kurikulární reformy. Orbis scholae, 1 (1), 111-130.

Beck, U. (2006). Vynalézání politiky. K teorii reflexivní modernizace. Praha: SLON.

Beck, U. (2004). Riziková společnost. Na cestě k jiné moderně. Praha: SLON.

Bridge, S. \& O`Neill, K. \& Cromie, S. (2003).Understanding Entreprise, Entrepreneurship and Small Business. Hampshire: Palgrave Macmillan.

Drucker, P.F. (2004). Fungující společnost. Praha: Management Press

Fayolle, A.\& Gailly, B..\& Lassas-Clerc,N. (2006). Effect and Counter-effect of Entrepreneurship Education and Social Contect on Student's Intensions. E Studios de Econimia Aplicada 24, (2), 509-523.

Giddens, A. (2003). Důsledky modernity. Praha: SLON.

Gibb, A. A.(2002) In pursuit of a new 'enterprise' and 'entrepreneurship' paradigm for learning: creative destruction, new values, new ways of doing things and new combinations of knowledg., International Journal of Management Reviews, 4, (3),233-269.

Gibb, A.A. (2007). Creating the entrepreneurial university: do we need a different model of entrepreneurship. In Fayolle, A. (Edt) Handbook of research in Entrepreneurship Education, 1, (s. 67-104). Edward Elgar Publishing

Chisholm, L. (2008). Prostupnost vzdělávání a orientace na kompetence: nové přesahy všeobecného a odborného vzdělávání. In Novotný, P. (Ed) Pracoviště jako prostor k učení. Inspirativní studie.(s.61-69) Brno: MU Brno 
Janík, T. \& Slavík, J. (2011). Učitel jako reflektivní praktik: podpora kvality realizace kurikula. In Janík, T., Slavík, J., \& Najvar, P. et al. Kurikulární reforma na gymnáziích: od virtuálních hospitací k videostudiím.1, 30-41. Praha: Národní ústav pro vzdělávání.

Janík, T. et al., (2010). Kurikulární reforma na gymnáziích v rozhovorech s koordinátory pilotních a partnerských škol. Výzkumná zpráva. Praha: Výzkumný ústav pedagogický v Praze.

Janík,T. (2005). Znalost jako klíčová kategorie učitelského vzdělávání. Brno: Paido.

Keller, Jan. (2007). Teorie modernizace. Praha: SLON.

Keynes J. M. (1963).: Obecná teorie zaměstnanosti, úroku a peněz. Praha: ČSAV.

Korthagen, F. (2001). Linking practice and theory; The pedagogy of realistic teacher education. London: Erlbaum.

Králová, A. (2007). Zvyšování kompetencí učitelů v předmětu ekonomika vyučovaném na středních školách. In Analýza kompetencí učitelů odborných ekonomických předmětů. Sbornék z mezinárodní vědecké konference, 36-40. Praha: VŠ́E.

Lazarová, B. (2005). Osobnost učitele a rezistence vůči změně. In Sborník prací Filozofické fakulty brněnské univerzity. Řada pedagogická. U10: Změny a inovace ve vzdělávání, 1, 109-122. Brno: Filozofická fakulta MU Brno.

Lynch, M. (2000). Against reflexivity as an academic virtue and source of privileged knowledge. Theory, Culture \& Society, 17 (3), 26-54.

Nader, C. (2010). Meet the alpha generation. Brisbane: Brisbane Times. Online: http://www.brisbanetimes.com.au/lifestyle/lifematters/meet-the-alpha-generation-20100320qmnr.html

Navrátil, P. (2009). Reflexivní využití teorie v procesu posouzení. (Studijní materiál). Online: http://is.muni.cz/el/1423/jaro2012/SPR819/um/Reflexivni_vyuziti_teorie_v_procesu_posouze ni.pdf

Pasch, M. a kol.(1998). Od vzdělávacího programu k vyučovací hodině. Praha: Portál.

Petty, G. (2008) Moderní vyučování. Praha: Portál.

Průcha, J., Walterová, E. \&Mareš, J. (2008). Pedagogický slovník. Praha: Portál.

Reich, R. B. (1995). Dílo národů. Příprava na kapitalismus 21. století. Praha: Prostor.

Sarasvathy, S. D. (2008). Effectuation. Elements of Entrepreneurial Expertise.

Cheltenham: Edward Elgar.

Sedláček, T. (2009). Ekonomie dobra a zla. Praha: Nakladatelství 65. pole.

Shackle,G.L.S. (1969). Ekonomika pro potěšení. Praha: Orbis.

Skalková, J.(2007). Kategorie cíle, kompetence, jejich vzájemný vztah a význam pro obsah vzdělávání v kontextu současnosti. Orbis Scholae,1 (1), 7-20.

Svoboda, M. (2002). Pojem fundamentální nejistoty v postkeynesiovské ekonomické teorii. Online: http://nb.vse.cz/ svobodam/Archiv_textu/Moje texty/Diplomka.pdf

Vašutová, J. (2004). Profese učitele v českém vzdělávacím kontextu. Brno: Paido, 2004.

Evropská komise (2009): Projekt Best Procedure: Podnikání jako součást odborného vzdělávání a př́ípravy.

Online: http://ec.europa.eu/enterprise/policies/sme/files/smes/vocational/entr_voca_cs.pdf 